\title{
ReVIEW I In the Midnight Hour: The Life and Soul of Wilson Pickett
}

\author{
Tony Fletcher
}

Oxford: Oxford University Press, 2017

ISBN: 9780190252946 (HB)

\author{
Roger Fagge \\ University of Warwick \\ roger.fagge@warwick.ac.uk
}

In recent years, we have gained a much better understanding of the emergence of soul music in post-war America. Some of this writing has taken the form of biography, covering many of the major performers of this period, and it is somewhat surprising that Wilson Pickett, a talented and important figure on the 1960s soul scene, has never been the subject of such a work. The fact that this is the first biography of Pickett is one of several appealing things about Tony Fletcher's well-researched book. Drawing on a wide reading of various sources, including a significant number of interviews, Fletcher offers a detailed and perceptive account of Pickett's life, and his rise and fall within the world of popular music. Pickett was born into a sharecropping family in rural Prattville, Alabama, in March 1941. He was a lively, determined child who embraced elements of rural life, including hunting and fishing, but disliked sharecropping, and his home life was less than settled. One of eleven children, he fell foul of his mother's temper, who during a violent outburst on one occasion fractured her son's arm. Fletcher suggests this explains in part Pickett's later violence against friends, relatives, partners, and children, as "a continuation of the way he was raised" (17). Indeed, this began early with the young Pickett threatening his brother James with a loaded rifle, an action that would be repeated with others in later years.

There was, of course, the music. And Pickett stood out early on as a talented singer in his family, singing in a gospel choir as well as in the fields as he worked and played. This included quartet singing which sometimes had as many as six performers, and emerged (Fletcher suggests) from the Jubilee and Barbershop traditions. However, Pickett also flirted with more secular material, encouraged by his possession of a radio that allowed him to access AM radio stations. His fellow Alabamans did not always appreciate this interest in secular music, 
however, and on one occasion he was hit with a heavy bible after getting caught singing a Louis Jordan number.

Pickett arrived in Detroit in 1956 (having previously lived there briefly when he was younger), and it was the right place at the right time for an aspiring southern singer, hoping to follow in the footsteps of other migrants who had in turn become successful in this music town. In a particularly interesting section of the book, Fletcher describes the vibrant musical culture of Detroit with Hank Bullard, Jackie Wilson, and others, including the theatrical Reverend C.L. Franklin, whose daughter Aretha became friends with Pickett. Franklin himself was recorded, and Pickett began touring "the gospel highways north and south" (31) with the group The Violinaires. In 1959, Pickett married his pregnant girlfriend Bonnie, although a shortage of money placed pressure on the relationship, as did Pickett's violent outbursts. That same year also saw Pickett move from gospel to secular music, mostly, it appears, for the extra earning potential it offered. He joined the ambitious Falcons who included Eddie Floyd, Mack Rice, and Robert Ward. With Pickett's trademark scream and charismatic performances, they soon attracted attention. Recordings followed, including "I Found Love", but The Falcons went their separate ways after a tussle with Atlantic Records over "If You Need Me", which Pickett had co-written, but Jerry Wexler gave to Solomon Burke. Pickett subsequently signed to Atlantic Records, where he formed a close if sometimes turbulent relationship with Wexler. Pickett's troubled marriage ultimately failed after he met Dovie Hall in 1962, who became an important influence on his life. In return she was subjected, amongst other things, to his paranoid jealousy and increasing domestic violence.

The Atlantic years saw the greatest successes of Pickett's career. Fletcher describes in detail various recording sessions, including in New York, Memphis, Muscle Shoals, and Philadelphia. These collaborations with musicians and producers are analysed by Fletcher, and he offers a judgement on the outcome of these sessions. Pickett comes across as a demanding perfectionist; an "egomaniac" (63) who was hardworking and encouraged a degree of respect from the musicians he worked with, but was also unnerving through his volatility. No one was quite sure of how he would respond, and irrationality and sometimes violence were on the cards. He was also controlling over money, which alienated some of his collaborators. Success followed but it was uneven. Whilst his live shows were highly acclaimed, his sales were less consistent, his big hits including "In the Midnight Hour" (1964) helped to rectify this to some extent. There are nods to the historical context, including black politics, in which Pickett, other than in a general resentment of racism, showed little interest. Pickett worked in integrated bands and with white musicians, and as time went on he moved towards a more (white) pop audience, following a different path to his rival James Brown. Covers of "Hey Jude" and other pop songs brought success, but also illustrated that he was more of an interpreter than a songwriter.

Pickett's star began to wane. Increasing income led to a flamboyant lifestyle and increased drug use and drinking. This in turn led to greater instability and a tendency towards violence that would eventually prove too much for the loyal Dovie. Falling out with Atlantic in 1972, largely due to disagreements over money, he received a million-dollar signing on fee with RCA the following year. Other than the odd track like "Mr. Magic Man", this relationship proved commercially and musically unsuccessful. Pickett was dropped by RCA in 1975, by which point he had come to regret his decision to leave Wexler and Atlantic. Pickett also had brushes with the law, including a year in jail for drunk driving in 1993. However, he benefitted from renewed interest in the classic era of soul, and 
was inducted into the Rock and Roll Hall of Fame in 1991. He also won a Grammy for his last album in 1999 and even co-starred in an award-winning D.A. Pennebaker documentary, Only the Strong Survive, in 2002. Pickett died of a heart attack, aged sixty-four, in 2006.

Tony Fletcher covers the ups and downs of Pickett's life, providing detailed accounts of recordings and important performances. He has written a great deal on music, including biographies, and this book is well written and approachable. At times, there is arguably too much specific detail, and it would have been helpful to have more on the social, cultural, political, and even musical context, in which Pickett operated. However, this is a valuable book, and it will be of interest to general readers interested in popular music, hardcore soul fans, as well as an academic audience. This is not fan literature but a serious and considered biography. Whether Pickett will be seen as significant as James Brown, Otis Redding and others is open to debate, but Fletcher has given us a good understanding of this talented but a flawed man. 